\title{
Oligopeptide Mapping of NP Proteins of Influenza A Viruses
}

\author{
(Accepted 14 August 1981)
}

\begin{abstract}
S U M M A R Y
Oligopeptide mapping of nucleoproteins (NP proteins) of 54 strains of influenza A virus showed the presence of both common and individual oligopeptides. Using the distribution of variable oligopeptides as the criterion, NP proteins were subdivided into four groups (NP0, NP1, NP2 and NP3). The NP0 group is composed of HON1 influenza viruses and the majority of animal influenza viruses. The NP1 group contains $\mathrm{H} 1 \mathrm{~N} 1$ (except $\mathrm{A} / \mathrm{California} / 78$ ) and $\mathrm{H} 2 \mathrm{~N} 2$ influenza viruses isolated from man as well as $\mathrm{H} 1 \mathrm{~N} 1$ influenza viruses recently isolated from animals. A/New Jersey/76 (Hsw1N1) influenza virus also belongs to the NP1 group. The NP2 group consists of H3N2 influenza viruses isolated from man and animals. A/California/78 (H1N1) influenza virus also falls into the NP2 group. The NP3 group contains NP proteins of four animal influenza viruses with the antigenic formulas Hsw1N2, Hsw1Nav2, Hav6Nav5 and Heq2Neq2.
\end{abstract}

Recent evidence has shown that the internal proteins of influenza A viruses are variable (Laver \& Downie, 1976; Brand et al., 1977; Dimmock et al., 1977; Schild et al., 1979; Erickson \& Kilbourne, 1980) and has revealed essential differences even in viruses of the same serological subtype (Dimmock et al., 1980; van Wyke et al., 1980; Young \& Palese, 1979; Sriram et al., 1980). It follows from this that a comparative study and categorization of the internal proteins are required. Attempts were made to classify nucleoproteins (NP proteins) using the $\left[{ }^{35} \mathrm{~S}\right]$ methionine labelling followed by oligopeptide mapping (Dimmock et al., 1980), and using monoclonal antibodies (van Wyke et al., 1980).

In the present study a tryptic oligopeptide mapping of ${ }^{125}$ I-labelled NP proteins of 54 strains of influenza A viruses was carried out. The data obtained show that NP proteins may be subdivided into four groups.

Viruses were grown in 10-day-old chick embryos and purified by centrifugation through 20 to $60 \%(\mathrm{w} / \mathrm{w})$ sucrose density gradients $(16000 \mathrm{rev} / \mathrm{min}, 16 \mathrm{~h}$ in a SW27.1 rotor of a Spinco L 5.50 centrifuge).

Ribonucleoprotein (RNP) particles were obtained by the method of Compans et al. (1972): virions were disrupted in buffer that contained $1 \%$ NP40, $0.5 \%$ sodium doexycholate, 0.01 M-NaCl, 0.01 M-tris- $\mathrm{HCl}, 0.001$ M-EDTA pH 7.2, lipids were extracted with ether, and RNPs were purified in 15 to $30 \%(\mathrm{v} / \mathrm{v})$ glycerol density gradients $(41000 \mathrm{rev} / \mathrm{min}, 5 \mathrm{~h}$ in a SW41 rotor of a Spinco L 5.50 centrifuge). RNPs were collected and pelleted by centrifugation. The purity of RNPs obtained by this method was established electrophoretically.

RNPs and virions were electrophoresed in $10 \%$ slab polyacrylamide gels by the method of Laemmli (1970). NP protein bands were cut out from the gels, washed in $10 \%$ methanol and lyophilized. ${ }^{125}$ I-labelling with chloramine-T (Sigma), digestion with trypsin (TPCK-treated, Worthington Biochemical Corporation), and two-dimensional analysis (electrophoresis followed by chromatography) on TLC plates $(10 \times 10 \mathrm{~cm}$, Merck) were carried out as described by Elder et al. (1977).

Oligopeptide maps of NP proteins of some influenza A viruses are shown in Fig. 1. It can be seen that NP proteins of various influenza A virus strains contain oligopeptides, some of 


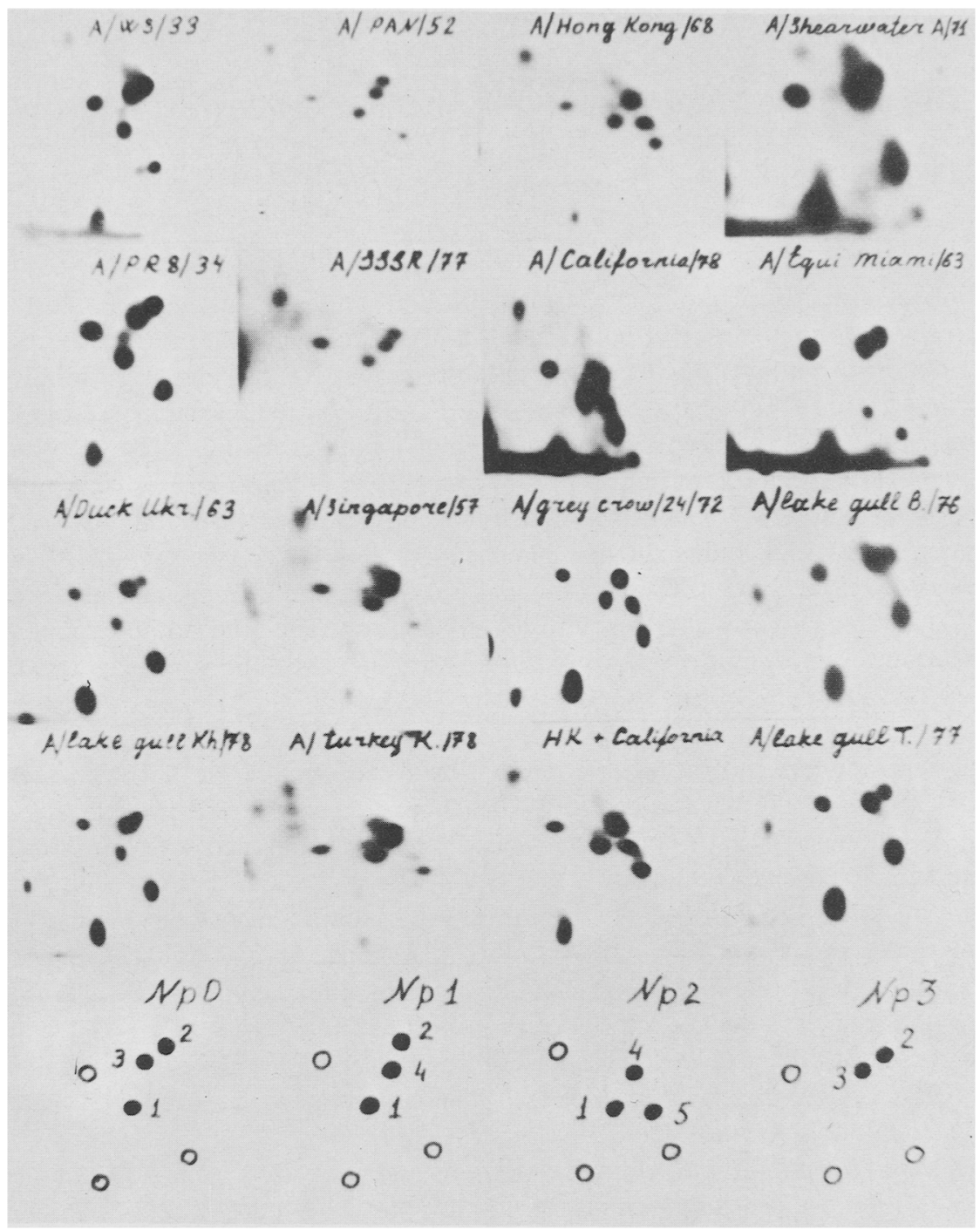

Fig. 1. Oligopeptide maps of NP proteins of some influenza A viruses. In the diagram, open circles indicate oligopeptides common to NP of all influenza viruses, and closed circles (numbered) oligopeptides partly common to NP0, NP1, NP2 and NP3.

which are common to all strains and some of which differ from one strain to another. Using the distribution of variable oligopeptides 1 to 5 as taxonomic criteria, NP proteins may be subdivided into four groups that we have designated NP0, NP1, NP2 and NP3. The NP0 group is characterized by oligopeptides 1, 2 and 3, the NP1 group by oligopeptides 1, 2 and 4, the NP2 group by oligopeptides 1, 4 and 5, and the NP3 group by oligopeptides 2 and 3. The co-runs of oligopeptides of NP proteins of various viruses (three to six pairs were analysed in each group) did not reveal intra-group differences in mobilities of marker oligopeptides. We also analysed mixtures of oligopeptides of NP proteins that belonged to different groups (results not shown).

These experiments showed that oligopeptide 1 is identical for NP0, NP1 and NP2, oligopeptide 2 for NP0, NP1 and NP3, oligopeptide 3 for NP0 and NP3, and oligopeptide 4 for NP1 and NP2. The maps of NP2 can be obtained from NP1 where oligopeptide 2 is 
Table 1. Grouping of NP proteins of influenza A viruses

\begin{tabular}{|c|c|c|c|}
\hline \multirow[b]{2}{*}{ NP group } & \multirow{2}{*}{ Influenza virus } & \\
\hline & & WHO (1971) & WHO (1980) \\
\hline NPO & A/WS/33 & HON1 & $\mathrm{H} 1 \mathrm{~N} 1$ \\
\hline NPO & A/WSN/33 & HON1 & H1N 1 \\
\hline NPO & A/PR $8 / 34$ & HON1 & $\mathrm{H} 1 \mathrm{~N} \mathbf{l}$ \\
\hline NPO & A/hazel-grouse/Vladivostok $1010 / 79$ & HON1 & H1N 1 \\
\hline NP0 & A/roe deer/Primorye 1201/79 & HON 1 & H1N 1 \\
\hline NPO & A/squirrel/Vladivostok 1004/79 & HON 1 & $\mathrm{H} 1 \mathrm{~N} 1$ \\
\hline NP0 & A/lake-gull/Khabarovsk/3794/73 & HONeq2 & H1N8 \\
\hline NP0 & A/whale/Pacific Ocean/76 & HONav2 & H1N3 \\
\hline NPO & A/duck/Tashkent/207/77 & H3N 1 & $\mathrm{H} 3 \mathrm{~N} 1$ \\
\hline NPO & A/chick/Khabarovsk/1082/78 & H3Neq 2 & H3N8 \\
\hline NP0 & A/swine/Iowa $/ 30$ & Hsw IN1 & $\mathrm{H} 1 \mathrm{~N} 1$ \\
\hline NP0 & A/equi/Praha/56 & Heq1NeqI & $\mathrm{H} 7 \mathrm{~N} 7$ \\
\hline NP0 & $\mathrm{A} / \mathrm{chick} /$ Khabarovsk/1056/78 & $\mathrm{Heq} 2 \mathrm{Neq} 2$ & H3N8 \\
\hline NPO & A/FPV/Rostock/33 & Hav1N 1 & H7N1 \\
\hline NP0 & A/turkey/Oregon/71 & Hav1Nav2 & $\mathrm{H} 7 \mathrm{~N} 3$ \\
\hline NPO & A/chicken/Germany/49 & Hav2Neq1 & H10N7 \\
\hline NPO & A/duck/England $/ 56$ & Hav3Nav1 & $\mathrm{H} 11 \mathrm{~N} 6$ \\
\hline NP0 & A/duck/Czechoslovakia/63 & Hav4Nav 1 & H4N6 \\
\hline NP0 & A/tern/South Africa/61 & Hav5Nav2 & H5N3 \\
\hline NP0 & A/turkey/Massachusetts/65 & Hav6Neq2 & H6N8 \\
\hline NPO & A/chicken/Tadjikistan/76 & Hav7N1 & H3N 1 \\
\hline NPO & A/duck/Ukraine/63 & Hav7Neq2 & H3N 8 \\
\hline NP0 & A/duck/California/72 & Hav7Neq2 & H3N8 \\
\hline NP0 & A/duck/Khabarovsk/72 & Hav7Neq2 & H3N8 \\
\hline NP0 & A/tern/Turkmenia/ 73 & Hav7Nav2 & H3N3 \\
\hline NPO & A/turkey/Ontario/68 & Hav8Nav4 & H8N4 \\
\hline NPO & A/turkey/Wisconsin/66 & Hav9N2 & H9N2 \\
\hline NP0 & A/duck/Alberta/76 & Hav10Nav1 & H7N6 \\
\hline NP1 & $\mathrm{A} / \mathrm{FMI} / 47$ & HIN I & $\mathrm{H} 1 \mathrm{~N} I$ \\
\hline NP1 & $\mathrm{A} / \mathrm{FW} / 50$ & H1N1 & H1N I \\
\hline NP1 & $\mathrm{A} / \mathrm{Pan} / 52$ & H1N1 & H1N 1 \\
\hline NP1 & A/Denver/56 & $\mathrm{H} 1 \mathrm{~N} 1$ & H1N1 \\
\hline NP1 & A/USSR/90/77 & H1N1 & H1N 1 \\
\hline NP1 & A/chick/Ukraine $32 / 77$ & H1N1 & $\mathrm{H} 1 \mathrm{~N} 1$ \\
\hline NP1 & A/turkey/Kiev 292/78 & HIN 1 & H1N I \\
\hline NP1 & A/red-head diver $21 / 78$ & HIN 1 & H1N I \\
\hline NP1 & A/Singapore/57 & $\mathrm{H} 2 \mathrm{~N} 2$ & $\mathrm{H} 2 \mathrm{~N} 2$ \\
\hline NP1 & $\mathrm{A} /$ Leningrad/80 & $\mathrm{H} 2 \mathrm{~N} 2$ & $\mathrm{H} 2 \mathrm{~N} 2$ \\
\hline NP1 & A/New Jersey/76 & Hsw1N1 & H1N1 \\
\hline NP2 & A/California/78 & H1N 1 & H1N 1 \\
\hline NP2 & A/Hong Kong $/ 68$ & $\mathrm{H} 3 \mathrm{~N} 2$ & $\mathrm{H} 3 \mathrm{~N} 2$ \\
\hline NP2 & $\mathrm{A} /$ England $/ 72$ & H3N2 & H3N2 \\
\hline NP2 & A/Port Chalmers/ 73 & H3N2 & $\mathrm{H} 3 \mathrm{~N} 2$ \\
\hline NP2 & $\mathrm{A} /$ Victoria/75 & $\mathrm{H} 3 \mathrm{~N} 2$ & H3N2 \\
\hline NP2 & $\mathrm{A} / \mathrm{Texas} / 77$ & $\mathrm{H} 3 \mathrm{~N} 2$ & $\mathrm{H} 3 \mathrm{~N} 2$ \\
\hline NP2 & A/Bangkok/2/79 & $\mathrm{H} 3 \mathrm{~N} 2$ & H3N 2 \\
\hline NP2 & A/duck/Kamchatka 2/71 & $\mathrm{H} 3 \mathrm{~N} 2$ & $\mathrm{H} 3 \mathrm{~N} 2$ \\
\hline NP2 & A/grey crow/Kazan $20 / 72$ & H3N2 & H3N2 \\
\hline NP2 & A/grey crow/Kazan $24 / 72$ & H3N2 & $\mathrm{H} 3 \mathrm{~N} 2$ \\
\hline NP2 & A/bat/Kazakhstan $73 / 76$ & H3N2 & $\mathrm{H} 3 \mathrm{~N} 2$ \\
\hline NP3 & A/lake-gull/Byelorussia 212/76 & Hsw1N2 & $\mathrm{H} 1 \mathrm{~N} 2$ \\
\hline NP3 & A/lake-gull/Turkmenia 13/77 & Hsw1Nav2 & H1N3 \\
\hline NP3 & A/equi/Miami/63 & Heq2Neq2 & H7N8 \\
\hline NP3 & A/shearwater/Australia 1/71 & Hav6Nav5 & H6N5 \\
\hline
\end{tabular}

replaced by oligopeptide 5. The maps of NP1 can be obtained from NP0 where oligopeptide 3 is replaced by oligopeptide 4 . The maps of NP3 are similar to those of NP0, but the former lacks oligopeptide 1 .

Table 1 summarizes the results of the study of 54 influenza A viruses isolated from man 
and animals. It can be seen from the table that NP proteins of human influenza $A$ viruses fall into three groups. The NP proteins of H0N1 (according to the old classification) viruses belong to the NP0 group; NP proteins of H1N1 viruses (except A/California/78) and of $\mathrm{H} 2 \mathrm{~N} 2$ viruses belong to the NP1 group; NP proteins of $\mathrm{H} 3 \mathrm{~N} 2$ viruses make up the NP2 group. The NP protein of A/California/78 (H1N1) virus also falls into the NP2 group. This is in agreement with the data of Young \& Palese (1979), who have shown that four genes of this virus, including $\mathrm{NP}$, originated from $\mathrm{H} 3 \mathrm{~N} 2$ viruses.

Animal influenza viruses fall into four groups. The majority of them that, according to the old classification, were designated as 'animal' subtypes (including $\mathrm{Hav} 7$ and Heq2) contain NP proteins of the NP0 group, which is characteristic for HON1 human viruses. In contrast, recently isolated animal influenza viruses similar to $\mathrm{H} 1 \mathrm{~N} 1$ and $\mathrm{H} 3 \mathrm{~N} 2$ human viruses possess NP proteins of the NP1 and NP2 groups that are characteristic for human $\mathrm{H} 1 \mathrm{~N} 1$ and $\mathrm{H} 3 \mathrm{~N} 2$ viruses. However, $\mathrm{H} 3 \mathrm{~N} 1$ and $\mathrm{H} 3 \mathrm{Neq} 2$ viruses isolated from animals have NP proteins of the NPO group. It is also interesting to note that NP protein of A/New Jersey/76 virus isolated from man, in contrast to a similar A/swine/Iowa/30 (Hsw1N1) virus, contains NP protein of the NPI group, whereas the latter has the NP protein of the NPO group. It is possible that the former virus is a recombinant that obtained NP from more recently isolated influenza viruses. NP proteins of four animal influenza viruses with the antigenic formulas Hsw1N2, Hsw 1Nav2, Hav6Nav5, and Heq2Neq2 make up the NP3 group which did not contain influenza viruses isolated from man. The peptide maps of NP3 are more similar to NP0 than they are to NP1 and NP2, which may reflect a closer relationship between NP3 and NP0.

Our data are basically consistent with the data obtained by Schild et al. (1979) using the immuno-double-diffusion method. They showed that NP proteins of HON1 and H3N2 human influenza viruses differ antigenically (we also subdivided them into different groups), and NP proteins of animal influenza viruses are closely related to the NP of A/PR8 (HON1) virus, whereas NP proteins of $\mathrm{H} 3 \mathrm{~N} 2$ swine isolates are antigenically related to NP proteins of human H3N2 influenza viruses (see Webster \& Schild, 1978).

Our grouping of NP proteins using the distribution of ${ }^{125}$ I-labelled oligopeptides does not coincide with that obtained by Dimmock et al. (1980), who compared ${ }^{35}$ S $]$ methioninelabelled oligopeptides, and with the grouping obtained by van Wyke et al. (1980) who used monoclonal antibodies. For example, Dimmock et al. (1980) placed the NP of A/PR8/34 virus in group 2, and $\mathrm{NP}$ proteins of $\mathrm{A} / \mathrm{FMI} / 47, \mathrm{~A} / \mathrm{HK} / 68$ and $\mathrm{A} / \mathrm{PCh} / 73$ viruses in group 1. We categorized the NP protein of $A / P R 8 / 34$ as NP0, NP protein of $A / F M I / 47$ as NP1, NP proteins of $\mathrm{A} / \mathrm{HK} / 68$ and $\mathrm{A} / \mathrm{PCh} / 73$ as NP2. Van Wyke et al. (1980) place NP protein of A/PR8/34 in category II, NP protein of A/FMI/47 in category V, NP protein of A/HK/68 in category III, and NP protein of $\mathrm{A} / \mathrm{PCh} / 73$ in category IV. Also, during each epidemic era [with the exception of $\mathrm{A} / \mathrm{California} / 78$ (H1N1)] we found only one NP protein group, whereas Dimmock et al. (1980) and van Wyke et al. (1980) found some differences in NP proteins of influenza virus strains isolated during the same epidemic eras.

The discrepancy between the data obtained by various methods may be explained by the fact that these methods do not compare whole NP protein molecules, but only certain restricted (and probably different) parts of them. How the similarities or differences of these parts of NP protein molecules reflect the common homology of NP proteins remains to be established. The discrepancies show that the final categorization of NP proteins may be achieved by the use of numerous independent methods, or by such direct methods as the establishment of full amino acid sequences of NP proteins. 


\section{REFERENCES}

BRAND, C. M., STEALEy, V. M. \& ROWE, I. (1977). Peptide mapping of ${ }^{125}$ I-labelled influenza virus proteins. Matrix proteins as markers in recombination. Journal of General Virology 36, 385-394.

COMPANS, R. W., CONTENT, J. \& DUESBERG, P. (1972). Structure of the ribonucleoprotein of influenza virus. Journal of Virology 10, 795-800.

DIMMOCK, N. J., CARVER, A. S., KENNEDY, S. I. T., LEE, M. R. \& LusCOMBE, s. (1977). Internal proteins of influenza virus ${ }^{35}$ S-methionine peptide maps as genetic markers. Journal of General Virology 36, 503-513.

DIMMOCK, N. J., CARVER, A. S. \& WEBSTER, R. G. (1980). Categorization of nucleoproteins and matrix proteins from type A influenza viruses by peptide mapping. Virology 103, 350-357.

ELDER, J. N., PICKETT, R. A., HAMPTON, J. \& LERNER, R. A. (1977). Radio-iodination of proteins in single polyacrylamide gel slices. Tryptic peptide analysis of all the major members of complex multicomponent systems using microgram quantities of total protein. Journal of Biological Chemistry 252, 6510-6515.

ERICKSON, A. H. \& KILBOURNE, E. D. (1980). Comparative amino-acid analysis of influenza A viral proteins. Virology 100, 34-42.

LAEMMLI, U. K. (1970). Cleavage of structural proteins during the assembly of the head of bacteriophage $T 4$. Nature, London 227, 680-685.

LAVER, W. G. \& DOWNIE, J. C. (1976). Influenza virus recombination. I. Matrix protein markers and segregation during mixed infections. Virology 70, 105-117.

SCHILD, G. C., OXFORD, J. S. \& NEWMAN, R. W. (1979). Evidence for antigenic variation in influenza A nucleoprotein. Virology 93, 569-573.

SRIRAM, G., BEAN, W. J., JR., HINSHAW, v. S. \& WEBSTER, R. G. (1980). Genetic diversity among avian influenza viruses. Virology 105, 592-599.

VAN WYKE, K. L., HINSHAW, v. S., BEAN, J. R. \& WEBSTER, R. G. (1980). Antigenic variation of influenza A virus nucleoprotein detected with monoclonal antibodies. Journal of Virology 35, 24-30.

WEBSTER, R. G. \& SCHILD, J. C. (1978). Summary of international workshop on the ecology of influenza viruses. Journal of Infectious Diseases 138, 110-113.

WORLD HEALTH ORGANIZATION (1971). Report: a revised system of nomenclature for influenza viruses. Bulletin of the World Health Organization 45, 119-124.

WORLD HEALTH ORGANIZATION (1980). Report: a revision of the system of nomenclature for influenza viruses: a WHO memorandum. Bulletin of the World Health Organization 58, 585-591.

YOUNG, J. F. \& PALESE, P. (1979). Evolution of human influenza A viruses in nature: recombination contributes to genetic variation of $\mathrm{H} 1 \mathrm{~N} 1$ strains. Proceedings of the National Academy of Sciences of the United States of America 76, 6547-6551.

(Received 5 May 198I) 